\title{
C-C Motif Chemokine 22
}

National Cancer Institute

\section{Source}

National Cancer Institute. C-C Motif Chemokine 22. NCI Thesaurus. Code C28735.

C-C motif chemokine 22 (93 aa, $11 \mathrm{kDa}$ ) is encoded by the human CCL22 gene. This protein is involved in the chemotaxis of monocytes, dendritic cells, natural killer cells and activated T-lymphocytes. 